\title{
G. K. Chesterton, Impressions irlandaises
}

Versailles, Via Romana, 2016

\section{Christophe Gillissen}

\section{(2) OpenEdition}

Journals

Édition électronique

URL : http://journals.openedition.org/etudesirlandaises/5202

DOI : $10.4000 /$ etudesirlandaises.5202

ISSN : 2259-8863

Éditeur

Presses universitaires de Rennes

Édition imprimée

Date de publication : 29 juin 2017

Pagination : 198-199

ISBN : 978-2-7535-5495-5

ISSN : 0183-973X

Référence électronique

Christophe Gillissen, « G. K. Chesterton, Impressions irlandaises », Études irlandaises [En ligne], 42-1 | 2017, mis en ligne le 29 juin 2017, consulté le 07 septembre 2019. URL : http://

journals.openedition.org/etudesirlandaises/5202 ; DOI : 10.4000/etudesirlandaises.5202 


\title{
Comptes rendus de lecture
}

\author{
Book Reviews
}

Beata Piatek, History, Memory, Trauma in Contemporary British and Irish Fiction, Krakow, Jagiellonian University Press, 2014, 197 p., ISBN 9788323338246, $9,25 €$.

Enseignante chercheuse à l'université Jagellonne de Cracovie, Beata Piatek s'intéresse aux relations complexes entre histoire, mémoire et trauma dans la fiction anglophone contemporaine. Son ouvrage, History, Memory, Trauma in Contemporary British and Irish Fiction, étudie quatre romanciers - deux Britanniques et deux Irlandais - dont les œuvres explorent les blessures du passé dans les sphères publiques et privées.

Le livre est composé de deux parties dont chacune comprend deux chapitres. La première partie, intitulée " History and Trauma ", se focalise sur des œuvres de Pat Barker et Sebastian Barry. La seconde, "Memory and Trauma ", est consacrée à des romans de Kazuo Ishiguro et John Banville. L'objectif n'est pas de comparer écrivains britanniques et irlandais, mais de montrer, à partir de leurs textes, la diversité avec laquelle sont appréhendés les événements du passé.

Ces analyses textuelles sont précédées d'un chapitre théorique qui recense chronologiquement les réflexions d'intellectuels sur la mémoire, à partir de Platon jusqu’à Pierre Nora, retrace les interrogations sur l'histoire soulevées notamment par le scepticisme postmoderne, et définit la notion de trauma et son évolution dans le cadre des trauma studies.

Intéressant et original, le propos développe des analyses pertinentes et convaincantes. Sebastian Barry, souvent considéré comme révisionniste, a tendance à ressasser les mêmes événements historiques tout en les traitant selon des points de vue de personnages différents. Piatek montre bien qu'au fil de ses publications, cet écrivain réagit aux critiques formulées sur son œuvre antérieure : par exemple, dans The Secret Scripture, Barry continue d'explorer des thèmes qui lui sont chers (les effets destructeurs des politiques nationalistes ou des secrets de famille), mais s'efforce aussi de porter un regard plus nuancé sur l'histoire irlandaise, qu'il n’aborde plus de manière simpliste et manichéenne comme il le faisait jusqu'alors. 
Tandis que Barry, dans ses "métafictions historiographiques ", narre les destinées de modestes personnages marginalisés, Banville, lui, se détourne de la fiction historique, bien que l'Histoire reste sous-jacente dans ses romans étudiés ici (Eclipse, Shroud et Ancient Light). Témoins d'un trauma, les protagonistes de Banville souffrent d'une mémoire envahissante et peinent à relire leur parcours comme un récit cohérent.

Les analyses des textes de Barker et Ishiguro sont également très stimulantes, même si le lecteur ne peut s'empêcher de penser que le trauma revêt une portée particulière pour ce dernier, né à Nagasaki dans les années 1950... Les spécificités propres au parcours de chaque écrivain risquent toujours d'être aplanies dans une étude globale et thématique de textes d'auteurs divers comme celle-ci, mais c'est là un écueil que Piatek parvient généralement à éviter.

En revanche, il aurait été intéressant de chercher à comprendre pourquoi les écrivains contemporains manifestent un tel engouement pour le passé individuel et la mémoire collective. Cet attrait se constate également dans les nombreuses autobiographies publiées ces dernières années. La recomposition de destinées personnelles et la réécriture d'événements historiques illustrent à quel point le passé peut être rejeté, interprété et transformé. Ce travail de remémoration et d'exhumation du passé est-il révélateur d'un besoin incoercible de s'interroger, s'examiner ou tout simplement, dans le sens du conseil socratique, de se connaître soimême? Ce mouvement de retour observable dans des textes publiés autour de l'an 2000 est-il à mettre en lien avec le changement de millénaire? Participe-t-il d'une démarche visant à mieux apprivoiser le présent et emprunter plus sûrement le chemin de l'avenir? Les raisons pour lesquelles ces thèmes sont si prégnants dans les textes de fiction contemporains auraient mérité d'être creusées davantage.

Indépendamment de ces remarques, l'ouvrage témoigne d'une excellente connaissance des romans, d'une grande maîtrise de l'appareil critique et des publications sur l'Histoire, la mémoire et le trauma, y compris les plus récentes. D'une écriture limpide, il se lit facilement et reste très accessible, d'autant plus qu'il n'est pas nécessaire d'avoir lu l'intégralité des ouvrages étudiés pour suivre et comprendre le propos.

Bertrand CARDIN 
Claude Fierobe, Les Ombres du fantastique. Fictions d'Irlande, Dinan, Terre de Brume, 2016, 206 p., ISBN 978-2-84562-586-2, 18,00 €.

Claude Fierobe, l'un des meilleurs spécialistes français de la littérature irlandaise, et en particulier de la littérature gothique, mais aussi l'un des " pères fondateurs " des études irlandaises en France, revient dans cet ouvrage sur ses lectures d'auteurs qu'il fréquente depuis longtemps, comme Charles Maturin ou Sheridan Le Fanu, mais commente également des écrivains tout à fait contemporains. Ce n'est pas un hasard si l'idée de "retour ", ainsi que celle de "fréquentation ", voire de possession, par certains tropes ou images récurrentes, nous viennent à l'esprit en parcourant cet ouvrage qui explore la relation unique qu'entretient la littérature irlandaise avec l'étrange, les mondes parallèles, et en particulier avec les revenants et autres esprits fantômes. Ce n'est pas tant que roman, théâtre et poésie irlandais abondent en apparitions surnaturelles, et en phénomènes inexplicables, mais surtout que tous ces textes font écho les uns aux autres de génération en génération, reprenant et retissant les images spectrales qui trouvent leur origine dans ce que Claude Fierobe appelle " les trois piliers " de la fiction fantastique irlandaise : Maturin, LeFanu et Bram Stoker. L'auteur nous entraîne à la suite de Melmoth dans un voyage qui traverse les siècles pour parvenir jusqu'à Joyce, Beckett, puis Banville, Trevor, Bolger, Neil Jordan, mais encore Joseph O'Connor, Colum McCann, Eoin McNamee, Claire Kilroy, Keith Ridgway, Paul Lynch, et d'autres. Il tisse un réseau entre des écrivains à priori éloignés les uns des autres, mais les apparences sont trompeuses. Tous par exemple sont visités d'une manière ou d'une autre par "le spectre du père », celui de James Joyce, lui qui a initié "l'incartade fantastique " au cœur du récit réaliste, en ayant recours aux épiphanies, à la méthode mythique, et par son ambition de faire proliférer le sens des mots et des images : les personnages jouent des rôles multiples, et ainsi tout se transforme.

Les écrivains irlandais sont également hantés par la question centrale de l'identité, d'abord celle de l'Irlande elle-même, éminemment floue et insaisissable. La question est abordée dans le seul roman " irlandais » de Bram Stoker, The Snake's Pass, que Claude Fierobe a traduit aux mêmes éditions Terre de Brume sous le titre Le défilé du serpent. Ses analyses font d'ailleurs écho à celles de Derek Gladwin qui consacre un chapitre à ce même roman dans Contentious Terrains. Bogs, Ireland, Postcolonial Gothic ${ }^{1}$ qui, étrange coïncidence (!), paraît en même temps que ce livre. Pour Claude Fierobe - comme pour Gladwin - " la tourbière est métaphore de l'imaginaire qui creuse le discours " (p. 57). Dans Star of the Sea de Joseph O'Connor, cette métaphore de l'inaccessibilité de la vérité et de la

1. Derek Gladwin, Contentious Terrains. Bogs, Ireland, Postcolonial Gothic. Cork University Press, 2016. 
dualité des apparences est celle du navire qui emporte les personnages ambigus qui fuient la famine vers un avenir incertain. Passé et futur se mélangent aussi étrangement dans Red Sky in the Morning de Paul Lynch qui met en scène la figure gothique du fugitif, et ressuscite la mémoire oubliée de cinquante-sept Irlandais morts sur un chantier de chemin de fer de Pennsylvannie. Claude Fierobe propose des rapprochements audacieux entre les écrivains qu'il convoque, comme celui qu'il établit entre John Banville, considéré comme un chantre du postmodernisme, et Dermot Bolger, généralement rangé parmi les auteurs traditionnels. Pourtant Claude Fierobe rend justice au goût de Bolger pour le néo-victorianisme, pour les intrigues labyrinthiques et les resurgissements d'un passé maudit. Claude Fierobe consacre également de longues analyses à Murphy de Beckett, écrivain chez qui il retrouve « un terrifiant ressassement » qui évoque « les plus fantastiques paysages intérieurs» (p. 143).

On appréciera l'écriture fluide et élégante de ce livre, qui n'a jamais recours au moindre jargon ni emphase, et qui n'est d'ailleurs pas de nature académique, mais qui permet à Claude Fierobe de laisser libre cours à une réflexion toute personnelle nourrie d'une connaissance intime de la littérature irlandaise. Cette fréquentation passionnée et assidue aussi bien des classiques du gothique, que des grand maitres Joyce et Beckett, mais aussi des œuvres les plus contemporaines, sert à nous offrir un survol presque vertigineux des thèmes récurrents de la littérature irlandaise, tels que l'aliénation, la folie, l'indétermination, l'entre-deux, la quête désespérée de l'identité, la fuite ou l'exil. Vue à travers " a glass darkly ", la littérature irlandaise semble distiller les sourdes angoisses d'une nation encore travaillée par un passé de dépossession, de violence, de faim, de soumission au religieux et d'exil.

Sylvie Miкоwsкi

Donald E. Morse (ed.). Irish Theatre in Transition. from the Late Nineteenth to the Early Twenty-First Century. Basingstoke, Palgrave Macmillan, 2015, 265 p., ISBN 978-1-137-45068-5, 65.25\$.

The title of Donald E. Morse's edited volume quotes the first sentence of the first essay in the collection, Christopher Murray's "The Irish theatre: The First Hundred Years, 1897-1997": "The best theatre is always in transition". The whole volume is intended as a homage to Murray's major contribution as a critic of Irish theatre, and more specifically as a response to this essay which was initially published in 1997, a hundred years after the inception of the modern Irish 
theatre in 1897. Murray's essay proposes a re-evaluation of the standard narrative of the history of modern Irish theatre, offering not one foundational moment (the creation of the Irish Literary Theatre in 1897) but a succession of re-foundations and paradigm shifts - from the initial Ibsenite model of the Little Art Theatre to Yeats's realignment with a Shakespearean model, after he visited Stratford-uponAvon in 1901 and, argues, Murray, "misread Shakespeare's history plays" as dissolving history into, as he phrased it, "'something almost mythological" (17). Another foundational moment in the history of Irish theatre coincided with the creation of the Irish Free State in 1922: only after this event can Irish theatre be "described as postcolonialist", Murray claims, thus controversially enforcing a strictly chronological understanding of the term and countering most definitions of postcolonialism as offered by postcolonial critics themselves. Thus resignifying the term "postcolonialist", Murray problematically hails O'Casey as "the first postcolonialist Irish dramatist", whose demythologising, revisionist agenda was henceforth picked up by such major figures as Behan, Friel and Murphy. In the final section of his essay, Murray looks towards female voices as possible alternatives to the largely bourgeois, modernist model of Irish theatre. Making a convincing case for the importance of the insufficiently remembered Alice Milligan in the beginnings of the modern Irish theatre, he points out the relative scarcity of contemporary women Irish playwrights, with the exception of Marina Carr and Paula Meehan. Almost twenty years after the initial publication of this essay, just as it was re-issued in this volume, the "Waking the Feminists" campaign, triggered in November 2015 by the outrageous under-representation of women playwrights and directors in the Abbey's programme for the centenary of the Easter Rising, revealed the extent to which gender discrimination still operates at every level in Irish theatrical institutions.

The fifteen essays that follow, all written by eminent critics of Irish theatre, almost always reference Murray's essay, though none of them really engages (critically or otherwise) with its revisionist agenda. Rather, they offer varied and often exciting insights about new developments in Irish theatre since the publication of the essay in 1997, and thus constitute a sequel to Murray's appraisal of "the first hundred years". In the first part, "Engaging with a Changing Reality", two essays by Eamonn Jordan and Maria Kurdi look at Celtic Tiger plays, while Jose Lanters' contribution offers an exciting reading of changing representations of queer sexualities in Synge, Behan, Kilroy and Friel. Finally, Donald E. Morse's piece registers the dramatic ageing of Irish population over the last two decades and provides a sensitive reading of the dramatisation of dementia in Frank McGuinness' The Hanging Gardens. The second part, "Enhanced Theatricality", is concerned with formal experiments in recent Irish drama. Csilla Bertha looks at modalities of metatheatricality in McGuiness' Carthaginians and Kilroy's The Secret Fall of 
Constance Wilde. Eric Weitz analyses the complex activity of laughing in experimental dramaturgies which dispense with the convention of the fourth wall and thus reconfigure the spectator-performer relationship. Ondřej Pilný convokes the categories of the grotesque and the sublime in a stimulating reading of Mark O'Rowe's Terminus. Part Four, "Reframing Transition", is concerned with performance history. Patrick Lonergan provides a highly informative survey of productions of Shakespeare at the Abbey between 1970 and 1985. Nicholas Grene shares his experience as Theatre Judge in 2006 and offers a selection of twelve snapshot descriptions of productions he attended in this capacity. Peter James Harris contributes a survey of productions of Irish plays in London "from Independence to the Present", and in the process usefully redefines what can be deemed an "Irish Play". Part Five, "Inventiveness and expanding the Stage", offers readings of experimental playwriting: Helen Heusner Lojek on Frank McGuinness and Joan Fitzpatrick Dean on Pat Kinevane's monologic explorations of abjection. Other essays in this section look beyond the stage at Irish dramatists' experiments with other media. Clare Wallace offers a compelling reading of Stewart Parker little known work for television, and Dawn Duncan writes about teaching Beckett on Film.

In the inaugural essay of the book, Christopher Murray quoted Philip Edwards' quip that Yeats had attempted to make Shakespeare "an honorary Celt". The volume comes full circle with Stephen Watt's elegant piece on Sam Shepard, which stands alone in the final part, "On the Re-Foundation of the Irish Theatre." Paying close attention to Shepard's 2007 play Kicking a Dead Horse, written for Stephen Rea, Watt argues that Shepard should be considered an honorary Irish playwright, and detects themes and patterns in his writing (like the focus on loneliness, the recurrence of regional speech patterns and the emphasis on storytelling) which place him in a venerable line of Irish playwrights from Synge to Beckett.

The close attention paid to the book's structure makes it more than a collection of disparate essays, and the volume constitutes an extremely valuable contribution to Irish theatre studies.

Alexandra Poulain

Keith Hopper and Neil Murphy (eds.), Dermot Healy, The Collected Plays, Dublin, Dalkey Archive Press, 2016, xxxIII+583 p., ISBN 978-1-56478-930$3,20,66 €$.

With Dermot Bolger's The Lament for Arthur Cleary (1989), the stage world of Connemara kitchens was decisively displaced by a play which was formally 
radical and broke with the traditional tropes of Irish theatre in presenting a bleak contemporary Dublin scarred by unemployment and heroin addiction. However, five years before Bolger's iconoclastic breakthrough, Dermot Healy's first play, Here, and There, and Going to America (1985), broke equally new ground in following the journey of a Sligo punk and his skinhead brother away from the local dole office to London as an intended staging post to the USA. The play covers 14 scenes, each introduced by "a character in top hat and tails who will turn over the pages on a noticeboard where in legible scrawl are the names of the scenes" which include a graveyard in Sligo and a squat in London. Now, with the publication of Healy's collected plays in the ambitious Dalkey Press project edited by Keith Hopper and Neil Murphy, we can see that throughout his thirteen plays, which date from 1985 to 2010, Healy was a restless experimenter with form and subject but also one who never settled into an individual style which developed depth and resonance.

Only four of Healy's plays were produced by professional theatre companies, Mr Staines (1999) by Pan Pan, On Broken Wings (1992) and Last Night's Fun (1996) by Omnibus Theatre and Metagama (2004) by Theatre Hebrides; with only Pan Pan still functioning as an active company. The rest were performed by various community and youth groups, schools, and prison inmates and, as in the case of Men to the Right, Women to the Left (2001) and A Night at the Disco (2006), frequently written in collaboration with them. As Healy said of his work with a school in Ballina, Co. Mayo, "It may be local and appear trivial, but to them at the time it was all important ... They wrote it, and I listened in."

The strength of Healy's drama is then its wholehearted commitment to giving voice to those outside of professional, Dublin theatre - and its audiences. Indeed only two of his plays were premiered in Dublin, the rest in Ennis, Clones, Castlerea, Drogheda, Ballina, Stornoway and, particularly, Sligo, with Healy directing eight of them. The result of this engagement with the non-metropolitan world of grass-roots theatre is a freedom to experiment and the plays are innovative in their use of swiftly flowing scenes, lights, masks and music. They range in subject from the absurdist meta-drama Mr Staines and the pacy, music-based comedy, Last Night's Fun (1996) to more realistic themes of the prison play, Serious (2005), and The Long Swim (1987) with its sensitive depiction of the effect of Alzheimer's Disease on a marriage.

The attraction of Healy's drama lies in its thematic variety and exploration of experimental staging - even in the most socially-engaged plays. But perhaps as a consequence of never establishing a partnership with an established company, such as that of Tom Murphy with Druid, which would have honed his dramatic skills, none of the plays achieve the power and mastery of his novels even while they share their concern with the displaced and marginalised. However, Healy's 
engagement with local groups makes him and his plays significant in a theatre culture so dominated by Dublin, and in a world where the Connemara kitchen is the default position of Irish drama, Healy's formal experimentation is to be celebrated. This first edition of his collected plays is to be welcomed as a valuable contribution to our understanding of the complex totality of Irish theatre.

Shaun Richards

G.K. Chesterton, Impressions irlandaises (préface de Pierre Joannon, avant-propos de Philippe Maxence, trad. Mathieu Grossi), Versailles, Via Romana, coll. «Les amis de Chesterton », 2016, 315 p., ISBN 978-2-37271-051-0, $12 €$.

G. K. Chesterton (1874-1936), homme de lettres anglais prolifique et toucheà-tout, a profondément influencé de nombreuses personnes à travers le monde, depuis des écrivains comme Jorge Luis Borges jusqu’à des philosophes tel Etienne Gilson, en passant par des républicains irlandais dont Michael Collins. Il reste pourtant quelque peu méconnu en France, et on ne peut que se réjouir que l'Association des amis de Chesterton ait mis à disposition du public francophone deux ouvrages rédigés par l'écrivain à l'occasion de visites en Irlande en 1918 puis en 1932 : Irish Impressions (1919) et Christendom in Ireland (1932). Il s'agit des premières traductions en français de ces textes, réunies ici en un seul volume, avec une introduction de Philippe Maxence, ainsi qu'une préface de Pierre Joannon qui réussit en quelques pages à brosser le portrait d'un personnage hors normes, doté d'une profonde sympathie à l'égard de l'Irlande.

Les deux textes furent écrits dans des circonstances fort différentes. En 1918, pendant la Première Guerre mondiale, l'Irlande était en plein émoi, l'introduction de la conscription par le gouvernement britannique ayant soudé la majorité de la population autour du Sinn Féin et de son projet indépendantiste. Personnalité publique affable et très appréciée, Chesterton fut envoyé en Irlande pour encourager ses habitants à participer à l'effort de guerre contre l'Allemagne. S’il avait dénoncé la répression brutale du soulèvement de Pâques 1916, il estimait, à l'instar de John Redmond, que l'enjeu de la guerre - la défense de la civilisation et de ses valeurs - était plus important que celui des clivages anglo-irlandais.

En 1932, converti de l'anglicanisme au catholicisme depuis dix ans, Chesterton se rendit au Congrès eucharistique international à Dublin, où Eamon de Valera et le Fianna Fáil venaient juste d'être portés au pouvoir, à la consternation de Londres. Il tenta de partager sa conviction que, loin d'être un territoire aux marges de la civilisation, l'Irlande, centre temporaire de la chrétienté, était moins 
provinciale et superstitieuse que l'Angleterre, et que sa population était animée d'un véritable esprit démocratique.

Ces contextes différents expliquent des textes de nature et de longueur très différentes. Le premier rend compte de la découverte de l'Irlande par Chesterton et de sa participation aux débats qui agitaient alors le pays. Pour en comprendre toute la finesse et l'intérêt, une bonne connaissance de l'histoire de la période est cependant nécessaire, car les nombreuses allusions à l'actualité de 1918 peuvent être déroutantes pour un lecteur non averti, même si l'introduction et la préface y remédient en partie. Le second texte, qui fait état de l'émerveillement d'un catholique anglais face à la lumineuse manifestation de la chrétienté à Dublin, constitue un témoignage de première main irremplaçable sur un événement souvent négligé par les historiens au profit de la riche actualité politique irlandaise de 1932.

Mais dans les deux cas, l'on retrouve le style inimitable de Chesterton, qui aimait à jouer de paradoxes et de jeux de mots, et à retourner les évidences dans des fulgurances bien plus sérieuses qu'elles n'y paraissent à premier abord. Cette prose n'est pas aisée à restituer en français, loin s'en faut, et il convient à ce titre de saluer la qualité de la traduction de Mathieu Grossi.

Christophe Gillissen 